\title{
Human Dignity and the Jewish Tradition
}

by

\author{
Hershey H. Friedman, PhD* \\ Professor of Business and Marketing \\ Brooklyn College \\ E-mail: $\underline{x . f r i e d m a n @ a t t . n e t ~}$
}

*The author wishes to thank Adam Deutscher for his help with this paper.

(C) 2008 H. H. Friedman 


\section{Introduction}

The concept of human dignity is crucial to all of mankind. The General Assembly of the United Nations adopted "The Universal Declaration of Human Rights" on December 10, 1948. Article 1 of the Declaration states: “All human beings are born free and equal in dignity and rights. They are endowed with reason and conscience and should act towards one another in a spirit of brotherhood." René Samuel Cassin, one of the major architects of this declaration, won the Nobel Peace Prize in 1968. He did not hide the fact that the idea of human dignity and rights came from the Scriptures (see his essay "From the Ten Commandments to the Rights of Man" available at: http://www.udhr.org/history/tencomms.htm). Human dignity is inextricably linked with human rights and belief in the brotherhood of all humankind.

Aramesh (2007) asserts that human dignity is a key concept in all theistic religions. In Catholicism, for example, it has its roots in the belief that humanity was created in the image of God (Imago Dei). Aramesh (2007) notes that human dignity is "one of the most emphasized themes in Islamic theology" and can be used by Moslems to resolve ethical questions in the area of bioethics and health care.

This paper will demonstrate how central human dignity (kvod habriot in Hebrew) is to Judaism. Rakover (1998: pp.29-30) cites Maimonides, Yaakov Emden, and other sources to show that kvod habriot applies to gentiles as well as to Jews (briot means creations); it also applies to the deceased as well as to the living. Hertz (1959: p. 265) declares: "The belief in the unity of the human race is the natural corollary of the unity of God, since One God must be the God of the whole of humanity... Through Hebrew monotheism alone was it possible to teach the Brotherhood of Man." 
There is a classic argument between Rabbi Akiva and Ben Azzai (Jerusalem Talmud, Nedarim 9:4) as to which is the fundamental principle that summarizes the entire Torah. Rabbi Akiva believed that it was the verse (Leviticus 19:18) "You shall love your fellow as yourself." Ben Azzai disagreed and felt that it was the verse (Genesis 5:1) "This is the book of the generations of Adam. On the day that God created man, He made him in the likeness of God." From the principle of loving your fellow human being as yourself, one can deduce "that which is hateful to you, do not do to others." This is Hillel the Elder's version of the Golden Rule (Babylonian Talmud, Shabbat 31a). A lofty ideal, but problematic if one does not much care about his or her own dignity. One who accepts the view that all of mankind was made in the likeness of God must respect all people, regardless of how s/he feels about her/himself (Pnei Moshe, see also Torah Temimah on Genesis 5:1). Indeed, Rabbi Joseph Soloveitchik, one of the great rabbinical leaders of the twentieth century, makes the point that human dignity and social justice "are implicit in the biblical concept that man was created in God's image" (Besdin, 1979: 190). Clearly, the importance of human dignity is linked to the belief that God created man. In fact, Amsel (1994) quotes the Midrash (Genesis Rabbah 24:7) that maintains when you insult another person you have insulted his Creator, because man was created in the image of God.

Maimonides (Mishneh Torah, Laws of Shmittah 13:13) makes a powerful statement that demonstrates the spiritual foundation of universal brotherhood.

Not only the tribe of Levi, but every single man of all the inhabitants of the world whose spirit and wisdom have inspired him to stand before God, to serve Him, to revere Him, to know God and to walk uprightly the way God made him; and he removed from his neck the yoke of the numerous calculations that people seek; this individual becomes sanctified, a Holy of Holies, and God shall be his lot and portion forever and ever ... 
If any inhabitant of the world has the potential of being a "Holy of Holies," one can understand why kvod habriot is so essential. The Talmud (Babylonian Talmud, Bava Kama 83b) makes a similar statement in a discussion dealing with the amount one must pay in damages for causing someone embarrassment (bosheth). The Talmud avers that damages depend on the status of the humiliator and of the humiliated. In other words, if a low- status individual insults a high-status individual more has to be paid in damages than in the opposite case. One opinion cited in the Talmud (ibid. 86a), however, is that "they are all the children of Abraham, Isaac, and Jacob." All have status.

In some cases where there is a question as to what is the law, the Talmud (e.g., Babylonian Talmud, Berachot 45a, Eruvin 14b) states: "Go out and see how the people are accustomed to act." Scholars can learn the law by observing how ordinary individuals behave. After all, they are the children of Abraham, Isaac, and Jacob.

Human dignity is of utmost significance in Jewish law. It is, however, of lesser importance than honoring and showing obedience to God. The Midrash (Midrash Genesis Rabbah, 90:2; Midrash Leviticus Rabbah 24:9) states that "My [God's] greatness will be higher than your [humankind's] greatness" and "My holiness is above your holiness." The point of this Midrash is to emphasize the prominence of humanity yet recognize that the principle of human dignity should not be used to disregard the laws of God. The Babylonian Talmud (Berachot 19b-20a), as we shall see, uses a verse from Proverbs (21:30) to derive the principle that "when there is a desecration of God's Name, no respect is paid [even] to one's teacher." Similarly, the Jerusalem Talmud (Chagigah 2:1; Midrash Genesis Rabbah 1:5) states: "One who gains honor through the degradation of his fellow human has no share in the World to Come. All the more so if one gains honor at the expense of the honor of the Eternal One." The Talmud is making it clear that the honor of God takes precedence over the honor of mortals. Linking human dignity with God's honor may be a good way to ensure that humankind respects both. 
People can never become as great as God; however, they can achieve godliness by engaging in such acts as helping the poor, healing the sick, and improving the world. The Talmud (Babylonian Talmud, Sotah 14a) derives the principle that humankind has the obligation to emulate the attributes of God from the verse (Deuteronomy 13:5): "You shall walk after the Lord your God." The Talmud notes that God made clothing for Adam and Eve, visited Abraham when he was ill, comforted Isaac after Abraham died, and buried Moses. Therefore people have the obligation to perform acts of kindness such as clothing the poor, visiting the sick, comforting the mourners, and burying the dead. The following verse in Leviticus (19:2): "You shall be holy for I the Lord your God am holy," is also used to derive the principle that mortals have an obligation to imitate God.

\section{Human Dignity in Talmudic Law}

The classic discussion regarding human dignity appears in the Babylonian Talmud (Berachot 19b-20a) where it states "The value of human dignity is so great that it supersedes a negative commandment of the Torah." The Babylonian Talmud concludes that human dignity overrides Rabbinic law and precepts of the Torah where the person is not actively engaged in a violation but is rather sitting and refraining from performing the commandment. In Jewish law, this is referred to as "shev v'al taaseh" (literally, sit and do not act). The opposite of a shev v'al taaseh is a kum aseh (literally, stand and act) an active transgression of Jewish law.

The Jerusalem Talmud has a somewhat different version of the above (Jerusalem Talmud, Berachot 3:1):

"The dignity of the public (the term used is kvod harrabim which means the dignity of the many) is so great that it supersedes a negative commandment of the Torah for one hour (i.e., temporarily)." Normally, the Torah (Leviticus 21: 1-3) does not permit the priest (kohen) to make himself ritually impure by coming into contact with a dead person (thus, he is not permitted to go into a cemetery) except 
for very close relatives. However, in certain cases involving human dignity, Torah law is superseded and the kohen is permitted to contaminate himself. The case discussed in the Jerusalem Talmud is one where the priest is part of a larger group that is going to do a good deed (e.g., redeeming a captive) and the group has a choice of two roads. The closer road passes over a place such as a cemetery which would make the priest ritually impure. According to many commentaries, this sort of impurity would be forbidden by the Torah. Even so, since it would be disrespectful of the group for the priest to leave, he is permitted to accompany them.

\section{Wearing a Forbidden Garment}

The Talmud (Babylonian Talmud, Berachot 19b) discusses the case where someone finds that he is wearing kilayim, i.e., shatnez (kilayim is a forbidden mixture; in the case of a garment it is one made of wool and linen - referred to as shatnez — and wearing it is a violation of a Torah precept) in public. The Talmud concludes that he must remove the garment even if he is standing in the marketplace and it will result in a loss of dignity since he has to walk home without his garment. The reason given is a quote from Proverbs (21:30): “There is no wisdom, nor understanding, nor counsel against the Lord.” The Talmud interprets this verse to mean that when there is a desecration of God's Name, no respect is paid [even] to one's teacher. This verse demonstrates that the honor of God overrides all human concerns, even that of human dignity. If an individual wears shatnez in public, s/he is desecrating God's name.

Maimonides (Mishneh Torah, Hilchot Kilayim 10:29) had a slightly different version of the above Talmudic text. Maimonides' Talmudic text did not have the word ba-bigdo (on his own garment). Thus, Maimonides states that if an individual sees another person wearing shatnez that is prohibited from the Torah, even if the person is in the marketplace, he is obligated to tear the garment off this individual immediately, even if the person is his teacher who taught him Torah. As noted above, when it comes to desecration of God's Name, even the respect of one's teacher is ignored. Thus, according to Maimonides, 
the obligation to remove shatnez in a public place applies both to one's self and even to others.

Maimonides notes that human dignity does not supersede a prohibition that is explicit in the Torah.

However, if the person is wearing shatnez that is rabbinically prohibited, then human dignity overrides

Rabbinical law and one can wait until the wearer of the forbidden garment gets home before tearing it off.

However, not all authorities agree with Maimonides; some believe (e.g., Rosh) that one is under no obligation to say anything when another party is wearing a forbidden garment and can wait until the other person gets home.

\section{Priests Becoming Impure}

As noted above, Jewish law prohibits a kohen (priest) from becoming ritually impure (the Hebrew word for this is tamei) by coming into contact with a corpse or even going into a cemetery. The Talmud describes the following case. A funeral procession is returning from a burial and the mourners take a road which was tamei (ritually impure, i.e., it passed over a grave). Out of respect for the mourner, the procession, even if it includes a priest (kohen) who as noted above is not permitted to become impure (tamei), may accompany the mourner. The Talmud (Babylonian Talmud, Berachot 19b) concludes that this case refers to a field where a grave has been plowed up so the bones are scattered about (beis hapras), where the prohibition against becoming impure is Rabbinic, and not a violation of Torah law. Normally, when one is permitted to walk through the field that contains a grave that has been plowed up (e.g., to offer the Passover sacrifice), he must blow on the ground in front of himself to blow the small bones that might be there. The Passover sacrifice — eaten by all Jews including non-priests — had to be eaten in ritual purity. In the above case, blowing on the ground is not necessary since it would be undignified in a funeral procession (Tosafot, Bechoros 29a).

The Jerusalem Talmud (Berochos 3:1) discussed previously disagrees with the Babylonian Talmud and states that human dignity supersedes the law prohibiting a priest from becoming impure in the case of the 
dignity of the public even if it is a contamination prohibited from the Torah. However, the Torah law is only superseded for a short period of time.

In another case involving priests, Rabbi Elazar b. Tzadok, who was a priest, stated that "we used to leap over coffins containing dead people in order to greet the kings of Israel. The Talmud adds that this is permitted even to greet Gentile kings so that if he is privileged to live in the times of the Messiah, he will be able to see the difference between the honor given to Jewish kings in Messianic times and Gentile kings (Babylonian Talmud, Berachot 19b). The Talmud concludes that climbing over a coffin is not a problem for a priest with regards to Torah law since coffins have a hollow space of a handbreadth and this serves to act as a barrier against the impurity of the corpse. Thus, it is only a violation of rabbinic law and human dignity overrides it.

\section{Returning a Lost Object}

The Torah requires that an individual return a found object to the rightful owner. The Torah (Deuteronomy 22:1) explicitly states: "You shall not see the ox of your brother or his sheep wandering and hide yourself from them." The Talmud (Babylonian Talmud, Berachot 19b) makes the observation that there are exceptions to this rule requiring that one return a lost object. One exception is an elderly person where it is beneath his dignity to deal with the lost object (it has very little value and he would not bother with it even if it were his own); he is permitted to ignore it. This is clearly a case where human dignity overrides a Torah law. The Talmud indicates that the reason we cannot generalize from here that human dignity always overrides Torah law is that returning a lost object is monetary law; monetary law is not as stringent as prohibitory law. The Meiri, a major commentary, notes that this is not a situation where the individual is actively violating Jewish law; rather, the individual is passive and refraining from performing the mitzvah of returning a lost object. The Talmud, however, prefers using the reason making 
the distinction between monetary law and prohibitory law. This implies that human dignity overrides Torah law if it deals with money, rather than prohibitory law.

\section{Burying the Dead}

There is a special law regarding a meth mitzvah, the burial of an unattended corpse (e.g., if a body is found in a lonely place and there is no one to take care of it). According to the Torah, even a priest or nazir is obligated to bury the meth mitzvah. A nazir (see Numbers 6:1-21) is an individual who consecrates himself by taking a special vow. The nazir was not permitted to drink wine, cut his/her hair, or come into contact with a corpse. Thus, if a priest or nazir is traveling and sees an unattended corpse on the side of the road and there is no one else to take care of it, he is obligated to bury it. Of course, this makes the priest impure and disqualified from priestly functions until he becomes purified. This is a case where human dignity (leaving a corpse unattended is an embarrassment for the deceased) overrides Torah law. Moreover, burying a corpse is not a passive case of sitting and not acting; after all, the priest is burying the deceased and is most certainly engaged in an act.

Many of the commentaries deal with this question as to why we do not use the case of the unattended corpse to derive a general principle that human dignity overrides Jewish law even in a case where the individual must actively violate a precept. Rashi's (Babylonian Talmud, Berachot 20a) answer is that the Torah law that a nazir or priest may not make himself impure by coming into contact with a corpse never included the meth mitzvah. Thus, human dignity does not override a Torah law; rather, this law never included a meth mitzvah. Tosafot rejects Rashi's answer and has a different explanation. The law of not becoming impure applies only to priests and does not apply to all Jews (it is a lav she'ein shaveh ba'kol); thus, one cannot make generalizations from it. The concept of lav she'ein shaveh ba'kol is used by other commentaries, not only Tosafot (see Meiri Berachot 19b who discusses this). The end result is that one 
cannot derive a general principle from the case of meth mitzvah that human dignity allows one to actively override Torah law.

The Talmud (Babylonian Talmud, Megilla 3b) demonstrates the importance of meth mitzvah by making it clear that if one has to choose between reading the Book of Esther (Megilla) on Purim - a rabbinical obligation - or burying the meth mitzvah, the individual must bury the dead person. Meth mitzvah is so important that even the High Priest (kohen gadol) must bury the unattended corpse.

The Talmud (Babylonian Talmud, Berachot 19b) notes that the obligation to bury a meth mitzvah overrides the law of offering the Paschal lamb (a positive precept of the Torah which cannot be performed by someone who has become unclean because of contact with a corpse) and the law to circumcise a son. Thus, an individual who is on his way to slaughter the Paschal lamb and encounters an unattended corpse will be obligated to bury the corpse even though this means that he will not be able to perform the mitzvah of eating the Passover sacrifice that year. Human dignity overrides Torah law in a case where there is a shev v'al taaseh (sit and do not act), i.e., the individual is passive and not performing the mitzvah, but not where the individual actively violates the Torah law. Not performing the commandment of offering the Paschal lamb is not the same as actively violating the prohibition against wearing shatnez.

\section{Violating the Sabbath}

In ancient times, people cleaned themselves with stones after defecating. The Talmud (Babylonian Talmud, Shabbat 81 b) concludes that one may carry the stones and use them for cleaning purposes on the Shabbat because of human dignity. This is a case where a rabbinical prohibition (there is an argument between two commentaries, Rashi and Tosafot, as to which rabbinical law has been violated by using the stones) is superseded by the concern for human dignity. 
A karmelit is an area that cannot be classified as either a public domain (reshuth harabim) or a private domain (reshuth hayachid). It is rabbinically prohibited to carry in a karmelit on the Sabbath. The Talmud (Babylonian Talmud, Shabbat 94b) discusses an incident where a corpse was lying in the town of Dakura and Rabbi Nachman b. Yitzchak permitted it to be moved into a Karmelit because of human dignity (Rashi speculates that the corpse may have been in the sun and there was a fear that it would rot or that the body was lying in a degrading place). Moving the corpse from a private domain to a karmelit on the Sabbath is a violation of rabbinic law which is superseded by human dignity considerations.

If it is the Sabbath and one is wearing a garment with tzizit (fringes) and one of the fringes tears, the individual must remove the garment. Since the tzizit are not valid anymore, he would be considered in violation of the prohibition against carrying. If the individual is in a karmelit (where the prohibition against carrying is rabbinical), he can walk home and wearing the garment; he is not obligated to remove his garment and walk home undressed. This is because human dignity overrides rabbinic law (Babylonian Talmud, Menachot 38a).

\section{Undeserved Goodwill}

Geneivat da'at (literally, stealing another's thoughts) is a term used in Jewish law to indicate creating a false impression and acquiring undeserved goodwill. It is prohibited and, according to most authorities, is a violation of Torah law. The Talmud (Babylonian Talmud, Chullin 94a) also states that one should not go to a mourner's house with a bottle of wine that is only partially full since this would be geneivat da'at. Apparently, in Talmudic times, comforters would bring bottles of wine for the mourners. An individual could easily bring a bottle that was nearly empty and strategically place it among the other bottles in a way so that the mourners would assume that the reason the bottle was empty was that people had drunk from it (see Maharsha). Nor should one fill the partially empty wine bottle with water since he deceives the mourner. This is also a case of geneivat da'at since the mourner will think he is being given a full 
bottle of wine. The Talmud adds that if there is a big assembly of people at the mourner's house and the comforter wants to show respect for the mourner (but cannot afford to bring a full bottle of wine), he is permitted the above deception. Clearly, if the purpose of the geneivat da'at is not to receive undeserved gratitude but to show honor or pay tribute to another person, it is permitted. Human dignity supersedes the prohibition against geneivat da'at.

\section{Mourning Laws}

An individual is being shaved and in the middle is told that his father died. He is permitted to have the job finished (Jerusalem Talmud, Shabbat 1:2). As a mourner for a parent he would not be permitted to take a haircut or shave his beard until his friends scold him for his unkempt appearance. However, walking around half-shaven or with half of a haircut would be very embarrassing and undignified. Therefore, because of kvod habriot, he is permitted to have the job completed (see Shulchan Aruch, Yoreh Deah 390:2).

Taking on a Stringency in Law

Dratch (2006) relates the following law to human dignity. The Talmud (Jerusalem Talmud, Berachot 2:9) permits even an ordinary person to adopt a chumra — legal strictness exceeding the normal requirements of the law - when it involves pain (e.g., fasting on certain days). However, it should be done privately; otherwise, it may cause embarrassment for others who do not act beyond the requirements of the law.

\section{Regulations Passed in Order Not to Shame Those of Limited Means}

Because human dignity is so important, the Talmud describes numerous enactments and laws that were passed in order to ensure that poor people were not embarrassed. 
Charity, ideally, should be given in secret so that the two parties, the giver and the receiver, do not know each other (Babylonian Talmud, Chagigah 5a; Maimonides, Hilchot Matnot Aniyim 10: 7 -14). Maimonides lists eight levels of charity: There is only one level above completely anonymous charity providing a poor person with employment. Providing a job to a pauper or giving him money in secret are the two best ways to preserve his dignity.

The Talmud (Babylonian Talmud, Moed Katan 27a-27b) notes that the following changes were enacted in the funeral ceremony in order not to embarrass the impecunious.

Our Rabbis taught: Formerly, they would bring food to the house of mourners in following manner: to the rich, in baskets of gold and silver and to the poor in wicker baskets made of peeled willows. And the poor people were ashamed. The sages, therefore, instituted that all should be provided with food in wicker baskets made of peeled willows out of deference to the poor.

Our Rabbis taught: Formerly, they would provide drinks to the house of mourners in the following manner: to the rich, in white glass [which was very expensive] and to the poor in colored glass. And the poor people were ashamed. The sages therefore instituted that all should be provided with drinks in colored glass out of deference to the poor.

Formerly, they would uncover the face of the rich [corpse] and cover the face of the poor because their face became blackened by famine. And the poor people were ashamed. The 
sages therefore instituted that all faces should be covered out of deference to the poor.

Formerly, they would carry out the rich [corpse] in a state bed and the poor on a common bier. And the poor people were ashamed. The sages therefore instituted that all should be carried out on a common bier out of deference to the poor...

Formerly, the expense of carrying out the dead was harder on the family than the death itself; the family therefore abandoned the corpse and fled. Until Rabban Gamliel [President of the Sanhedrin] disregarded his own dignity, and had his body carried out in flaxen shrouds. Afterwards, all the people followed his lead and had themselves carried out in flaxen shrouds. Rabbi Papa stated: And nowadays, all follow the practice of being carried out even in a canvas shroud that costs but a $z u z$.

Friedman (2003) discusses the halachic issues involved in living an ostentatious lifestyle. Judaism is concerned about any behaviors that will shame those of limited means. This was the rationale for many sumptuary laws that were passed by Jewish communities throughout history.

The Talmud (Babylonian Talmud, Pesachim 82a) discusses why an individual was not permitted to burn a Paschal lamb that became ritually unclean in front of the Temple with his own wood. Rabbi Yosef offers the following reason: The sages did not want to embarrass the poor people who did not have their own wood so they, therefore, enacted that everyone had to use the altar wood that belonged to the Temple. 
Regulations Passed in Order Not to Shame the Ignorant

The Mishna (Bikkurim 3:7) relates that at first those who knew how to recite the prayer of gratitude to God (in Hebrew) — said when bringing the bikkurim (first fruits) to the Temple (see Deuteronomy 26: 112) - would recite them; those that could not would repeat the words of the prayer after hearing the priest say them. This caused a great deal of embarrassment for those that were ignorant so they refrained from bringing the first fruits. The rabbis therefore enacted that both the person who knew how to recite the blessings and one who did not know would repeat the words.

\section{Human Dignity in Post-Talmudic Jewish Law}

The principle of human dignity was not only an issue in Talmudic times. Many modern questions that come up in Jewish law are decided upon using this principle. This is only a sample of legal questions that have used the principle that human dignity is so great that it supersedes a negative commandment of the Torah.

\section{The Cheating Spouse}

The Noda Be-Yehuda (Orech Chaim, Responsa 35) deals with a fascinating case. A young student had an affair with his hostess, a married woman, for several years. Subsequently, he married her daughter. In Jewish law, if a married woman commits adultery, she is prohibited from having intercourse again with both her husband and the adulterer (even after she is divorced). The young student decided to do teshuvah (penance) for his sin and wanted to know whether he was obligated to tell his father-in-law about his affair. The question was whether kvod habriot was a good enough reason to permit the penitent son-in-law to "sit and not act" and not inform his father-in-law of what he had done. The fear was that making the adultery public would cause a great deal of embarrassment for the entire family, including the 
children who were very respected. The Noda Be-Yehuda related this question to the above-mentioned argument between Rambam and the Rosh. Rambam, who stated that one must tear off shatnez worn by another in the marketplace, would believe that the adulterer should tell his father-in-law what he had done. The Rosh, whose opinion is that one is not obligated to tell another party that he is wearing shatnez, would feel that the son-in-law may "sit and not act" and not say anything. The Noda Be-Yehuda discusses other issues (the reader is urged to go to the original source) and concludes that the son-in-law must tell his father-in-law in private what he had done. This will ensure that the father-in-law will believe him since the truth has a way of making itself known. Otherwise, the father-in-law might continue to have sexual relations with his wife and, as noted above, she is no longer permitted to him. Since the father-in-law was an older man and would not remarry anyway, the Noda Be-Yehuda was able to come up with a solution that would not cause a public embarrassment. He states that the husband is under no obligation to divorce his wife; he is simply not permitted to have relations with her. Thus, they may remain married and continue to live together in the same house but never again have sexual relations. Of course, the public and family would not know about the wife's infidelity since the couple would continue to be married. This would spare the family from being embarrassed.

The Divrei Chaim (She'elot U'Teshuvot Divrei Chaim, Orech Chaim 35), on the other hand, felt that since the prohibition against living with a wife who has committed adultery is not explicitly stated in the Torah, the adulterer should keep the affair secret because of kvod habriot.

A similar case is that of a woman who was promiscuous when she was younger and had an abortion. Later on she changed her ways, married, and gave birth to a son. Once a woman has an abortion, there is no longer an obligation to perform the ritual of pidyon haben (redemption) on a first-born son; after all, the child is not the first born. However, since no one knew of the women's past, it would be very embarrassing for the family not to have a pidyon haben. Permitting the pidyon haben, on the other hand, 
means that unnecessary blessings will be made. Indeed, the entire ceremony would be a sham. Feldman mentions this problem and provides sources that discuss this question in detail (2005: p. 203).

\section{Human Dignity and the Sabbath}

\section{Hearing Aids and Electric Wheelchairs}

To understand this case, one must be aware of the law of muktzeh. The rabbis prohibited moving certain objects on the Sabbath as a preventive measure. By avoiding muktzeh objects (e.g., money), one is less likely to violate the Sabbath. A hearing aid is muktzeh as are almost all electrical devices and machines. Rabbi Eliezer Yehuda Waldenberg (Sheilot U'Teshuvot Tzitz Eliezer 6:6) states that a deaf person may wear a hearing aid on Shabbat since the principle of human dignity overrides the problem of muktzeh. After all, it is extremely embarrassing for a person to go to the synagogue and not be able to respond to people who talk to him. In addition, there is a great deal of mental anguish for a person to go to a synagogue and be unable to listen to the reading of the Torah, pray along with others, and perform other mitzvot. Rabbi Waldenberg compares this to the case of using stones for cleansing oneself. Human dignity supersedes the rabbinic law not permitting one to use something that is muktzeh on Shabbat.

Closely related to this issue is the problem of an electric wheelchair on Shabbat or Yom Tov. The Zomet Institute in Israel designed an electric wheelchair for Shabbat use that does not involve the violation of any Torah laws. The source of the electricity in such a wheelchair is a battery; a battery releases power stored from before the Shabbat and does not generate power. The development of such a wheelchair was encouraged by Rabbi Shlomo Zalman Auerbach, a well-known religious authority, who felt that being forced to stay at home for several days results in a loss of human dignity and self-worth. Therefore, $k$ vod habriot overrides any problems with muktzeh and other rabbinic violations (Meir, 1990). 
Meir (1990) quotes the Kalkelet HaShabbat who permits the opening an umbrella on Shabbat in special cases where human dignity is involved. As far as insisting that a person remain indoors all Shabbat, "there is no greater anguish than that" (based on Tosafot, Shabbat 50b, s.v. "bishvil"). Tosafot explicitly states that there is no greater pain than being ashamed to go out among people (and thus having to stay indoors).

\section{Getting Married on the Sabbath}

One is not permitted to get married on Shabbat. This is rabbinically prohibited because of a fear that one may come to accidentally write something; writing on the Shabbat is a violation of Torah law. There was a custom in many communities to get married on Friday afternoon. What is the law if the financial/dowry arrangements take very long and it is nightfall, i.e., the beginning of Shabbat: may the wedding be permitted? According to the Remah (Shulchan Aruch, Orech Chaim 339:4), we permit the wedding to take place on the Shabbat. Since the wedding meal is already prepared and it would be very embarrassing for the bride and groom not to get married, we use the principle of human dignity to allow the wedding to take place.

\section{Medications on the Sabbath}

There are opinions that allow one to take medications on Shabbat if there is concern for kvod habriot. For example, if one has a very bad runny nose s/he may be permitted to take medicine for this since it is undignified to walk around like this. The same may be true for allergy medications and antacids if the person is afraid that not taking the medication may result in some embarrassment (Jachter, 2001).

\section{Tearing Toilet Paper}

What is someone supposed to do on Shabbat if he finds himself in the bathroom and there is no pre-torn toilet paper or tissues? Many authorities feel that tearing toilet paper on Shabbat is a violation of Torah law since it is being torn for a constructive purpose (see Mishna Berurah 340:41). If it is prohibited from 
the Torah, the solution is to tear it with a shinui (a way that is different than the usual way, e.g., holding the toilet roll in place with an elbow and tearing off the paper with the other hand). Tearing with a shinui lowers the prohibition to a violation of Rabbinic law which is set aside for kvod habriot (see Shmirat Shabbat K'hilchata 23:16).

Closely related to the above is the law that one is permitted to build on Shabbat a temporary toilet made out of stones to sit on when relieving oneself. Building a temporary structure on Shabbat would be a violation of Rabbinic law but is permitted because of kvod habriot (Shulchan Aruch, Orech Chaim 312:9). Also, a case discussed by Rabbi Abraham Weinfeld (Lev Avraham, 1: 52) regarding washing and scrubbing one's beard on Shabbat if it has become filthy. He permits the scrubbing of the beard —not only simply making it wet - if there is a question of kvod habriot and there is no other way to get the beard clean.

\section{Wearing a Handkerchief on the Sabbath}

The Levushei Mordechai (Sheilot V'Teshuvot Levushei Mordechai, Orech Chaim 2: 133) discusses the problem of wearing a handkerchief around one's neck on Shabbat where there is no eruv. It is obvious to everyone that the handkerchief is not being worn as a scarf, particularly when the weather is not cold. Indeed, it is very obvious if the handkerchief is worn on top of a scarf. Clearly, it is a noticeable legal fiction to get around the law (haaramah) and should not be permitted. He, however, notes that the Chatam Sofer wore a handkerchief around his hand. It is permissible because taking something outside the eruv in an unusual manner (hotza'ah shelo k'darko) is Rabbinically prohibited. Kvod habriot supersedes rabbinical law; it is embarrassing for someone with a runny nose to walk around without a handkerchief.

\section{Colostomy Bags}


Some individuals have to wear a colostomy bag under their clothing after surgery. This can be a problem on Shabbat in a public domain (reshuth harabim) where there is no eruv. This question relates to an issue that is discussed in the Shulchan Aruch (Orech Chaim 301:13) regarding the zav (individual suffering from venereal discharges) who wears a pouch under his clothing to protect them from becoming soiled. One may not go into a reshuth harabim with the pouch since its only purpose is to protect the garments from becoming besmirched. Wearing something in order to protect one's clothing from being soiled does not give the worn item halachic status as a garment (malbush); thus using it constitutes carrying. The same is true of a woman who wears something under her clothing to protect them when she is menstruating. However, if something is being worn to reduce pain, it is permitted. The issue of wearing a colostomy bag and going into a reshuth harabim is discussed by Rabbi Abraham Weinfeld (Lev Avraham, 1: 46) and he uses the principle of kvod habriot to permit going outside with the bag. He also relies on the above-mentioned Tosafot (Babylonian Talmud, Shabbat 50b, s.v. "bishvil") and avers that the psychological pain of shame is no worse than physical pain.

\section{Getting Called up to the Torah}

Normally, one is called up to the Torah using one's name followed by “son of (ben) father's name, e.g., Shimon ben Yaakov. What happens if one's father was a heretic and it is an embarrassment for the son to be called up using his name? The Remah (Shulchan Aruch, Orech Chaim 139:3) allows the person to be called up using the grandfather's name. If the son was an adult and was accustomed to be called up using his father's name and now his father has become a heretic, we continue to use the father's name. It would be embarrassing to make a change in the name; a change would draw attention to the fact that the father is a heretic. These laws were established because of human dignity, we do whatever is possible to minimize the embarrassment of the person being called up to the Torah. 
Closely related to the above case is the situation where a woman does not know the name of her father. This causes problems with her kethubah (marriage contract), since a name must be mentioned. What makes it even more complicated is that the kethubah is read out loud for all the wedding guests to hear and we do not want to embarrass the couple. One solution is to write the bride's name in such a manner: Rachel, who is called Rachel daughter of Jacob, (Rochel bas Yaakov), if she was raised by Jacob. Of course, this is a giveaway that Rachel is not really Jacob's daughter. Therefore, when the kethubah is read out loud, we either skip the words "Rachel who is called" or say it quickly so those words are not heard (Sheilot V'Teshuvot Minchas Yitzchak 5:44).

\section{Cases involving a Priest (Kohen)}

As noted above, a kohen (priest) is not permitted to make himself tamei (impure) by coming into contact with a corpse. Thus, if there is a dead person in a room, a kohen should not enter the room. Suppose a priest is sleeping in a room and is naked and someone dies in the room. There is no question that he must leave the room as soon as he is aware that there is a corpse there. Is he permitted to get dressed? This is a question that is discussed by many commentaries. The Remah (Yoreh Deah 372) says the priest must leave the room immediately and is not permitted to spend even a moment getting dressed. Others disagree with the Remah and consider spending a few seconds getting dressed as a shev v'al taaseh (passive) prohibition which is superseded by human dignity. They allow the priest to put on enough clothing to maintain his dignity (e.g., a robe), but not to get completely dressed (Panim Me'irot 2:27).

Rabbi Shlomo Kluger (Teshuvot Tuv Taam Vedaat 3:2:211) discusses the case where a kohen is leading the services on Yom Kippur and an individual dies in a room next door. He concludes that it is a great embarrassment for the shliach tzibbur (individual leading the prayer or cantor) to interrupt the prayers and leave the reader's desk (tayvah) empty. Therefore, we do not inform the shliach tzibbur that someone has died and allow him to finish the prayer services. 
The following question concerns a kohen whose finger was accidentally cut off so it was hanging and the surgeon would first have to remove it totally before reattaching it. The problem is that once the surgeon removes the finger it is an organ from a living creature and will contaminate the kohen (make him tamei). As discussed above, a kohen is not permitted to contaminate himself. Rabbi Sternbuch (Teshuvot V'Hanhagot, 4: 262) uses the argument that kvod habriot enables us to supersede the prohibition against becoming ritually impure (tamei), even where there is an active transgression (kum aseh) of Jewish law. It is certainly quite embarrassing to walk around with a partially attached finger. He does, however, recommend using a gentile surgeon and putting the kohen to sleep so he does not assist in any way.

\section{$V$. Having an Abortion}

Rabbi Eliezer Yehuda Waldenberg (Sheilot U'Teshuvot Tzitz Eliezer 9:51:3) states that abortion is permitted in the following situation: If a married woman either had an affair (then repents) or was raped and she has become pregnant. This is a case where there is great embarrassment for the family; therefore, we allow the abortion because of human dignity. Jewish law considers psychological factors as well as physical factors in deciding whether or not an abortion is permitted. It should be noted, however, that even when abortion is permitted, Jewish law makes distinctions between early-stage and late-stage abortions. (Those interested in knowing more about abortion and Jewish law may be interested in reading Dr. Daniel Eisenberg's article at: http://www.aish.com/societyWork/sciencenature/Abortion_in_Jewish_Law.asp)

\section{Dyeing one's Beard}

The Torah (Deuteronomy 22:5) prohibits a man from wearing women's clothing (and vice versa). The Talmud includes under this prohibition men who groom themselves the way women do, e.g., shaving underarm hair (Babylonian Talmud, Nazir 59a) or plucking out white hairs (Babylonian Talmud, Shabbat 94b). This law would also apply to a man who wishes to dye his hair or beard for grooming purposes. An 
interesting question arose when half of the beard of a young person mysteriously turned white and he was embarrassed with it. He asked whether he would be permitted to dye his beard black. He was permitted to dye his beard because of human dignity (Sheilot U'Teshuvot Shoel U'Meishiv 1:1:210).

\section{Playing Music on the Second Day of Yom Tov to Honor the King}

Rabbi Meir Simcha Cohen of Dvinsk (Ohr Someach, Hilchot Yom Tov 6:14) permits musicians to play music on the second day of Yom Tov in order to honor the king. Celebrating the second day of Yom Tov outside of Israel nowadays is a minhag (custom) and is superseded by kvod habriot. The Ohr Someach relates this case to the one above dealing with leaping over coffins in order to greet kings.

The Ohr Someach also discusses another issue: May one make garments on Chol Hamoed for a brith milah (circumcision) for a child that was born on the first or second day of Sukkot because of kvod habriot? This is a question that is discussed in the Rivash (1:226). The Rivash feels that it is not much of an embarrassment for the father if the infant does not wear new clothing. The Ohr Someach also does not permit it. He states that we use the principal of kvod habriot if the mitzvah that will be superseded and the embarrassment occur simultaneously; the act of not doing the mitzvah removes the embarrassment. For instance, allowing the Kohen to bury the unattended corpse (and thereby becoming tamei) eliminates the embarrassment of having an unburied body. In this case, while the garment is being sewn, the person is not being saved from any embarrassment. The embarrassment will occur in the future at the brith ceremony and the family does not have nice clothing to wear.

\section{Mourning a Person Who Committed Suicide}

Suicide is a serious transgression in Jewish law (Babylonian Talmud, Bava Kama 91b), since one’s life belongs to God. One who commits suicide is not entitled to mourning rites (i.e., sitting shiva and rending of clothes) or supposed to be eulogized. Only rites that are for the honor of the survivor, e.g., lining up at 
the conclusion of the burial, should be performed (Shulchan Aruch, Yoreh Deah 345:1). There are, however, some situations where the family is permitted to mourn the person who committed suicide. This is the case when it will cause the family a considerable amount of embarrassment that a member committed suicide, we allow the family to mourn. The Chatam Sofer (Sheilot V'Teshuvot, Yoreh Deah 326) adds that when it comes to the embarrassment of the family (pegam mishpacha), we do not follow any view that is lenient with the dignity of the children of Abraham, Isaac, and Jacob. The law discussed above regarding one who commits suicide is referring to one who did it with a clear head and had no regrets while committing the act. If this is the case, he has to be buried in a special part of the cemetery away from the Jewish graves. In most all cases, the assumption is that the person who committed suicide was not totally rational so the deceased is treated like any Jew (Weiss, 1991: 81-82). The fact that we make the assumption that the person who committed suicide was temporarily insane and treat the deceased like any other Jew probably has a great deal to do with the fact that we wish to spare the family additional pain.

\section{Resisting the Urge to Eliminate}

It is not clear whether or not the prohibition against holding back the urge to eliminate is Biblical or Rabbinic (Shaarei Teshuva,Shulchan Aruch, Orech Chaim 17). The Talmud (Babylonian Talmud, Maakot 15b) derives the prohibition from the verse (Leviticus 11:43): "You shall not make yourself abominable..." This may, however, be an asmakhta (the verse hints at the prohibition and provides support for it, but it is not biblical). Regardless, if one has the urge, because of kvod habriot, s/he may wait until an appropriate, private place is found (Pri Megadim, Orech Chaim, Mishbetzot Zahav 3:7:13).

If the individual leading the services (shliach tzibbur) discovers he has the urge to relieve himself in the middle of the tefilla (prayers), he may complete them because of kvod habriot (Magen Avraham, Shulcahn Aruch, Orech Chaim 92:2). 


\section{Town with one Etrog (citron)}

Rakover (1998) discusses a query in a sefer by Rabbi Dovid Pardo (Sheilot V'teshuvot Michtam L'Dovid, Orech Chaim 6). A town had only one etrog (citron) and was asked by an emissary of another town that did not have any etrogim to give it to them so that they could do the mitzvah during chol hamoed. The people of the first town had already performed the mitzvah during the first two days of Sukkot. Rabbinical law, however, requires that the four minim be used during chol hamoed. Rabbi Pardo used the argument of kvod habriot - the town without the etrog would suffer greatly if they could not perform the mitzvah at all - and said that the town with the etrog should give it to the other town. After all, they sent a messenger with the hope that he would bring back an etrog for them. Were he to return empty-handed, it would cause them great sorrow. There is no greater kvod habriot than allowing the people from the other town to have an etrog, even if this means that the people of the first town will not be able to do the mitzvah during chol hamoed.

\section{Humiliation of a debtor}

Not paying a debt is a violation of Torah law. The Talmud (Babylonian Talmud, Bava Kama 11b) states that the creditor has the right to take "even the cloak off the shoulder of the debtor." Tosafot, however, notes that this is only true if the debtor possesses more than one cloak or if the debtor owns a very expensive cloak. In the latter case, we force the debtor to exchange it for a less expensive garment. Rakover (1998: p. 139) cites sources such as the Maharam (Teshuvos Maharam 400) that clearly make the point that because of human dignity we do not allow a creditor to take the only garment of the debtor. This is the law despite the fact that it is a mitzvah (commandment) from the Torah to pay one's debts.

The Shulchan Aruch (Choshen Mishpat 97:2) emphasizes that a creditor should try to avoid being seen by the debtor if he knows that latter does not have the means to repay the debt because a person who owes money and cannot pay back will be ashamed. 


\section{Conclusion}

Malachi said (2:10): "Have we not all one father? Has not one God created us? Why do we deal treacherously every man against his brother...?" Human dignity is based on the belief that we were all created in the image of God. Prejudice, racism, and sexism are totally inconsistent with Torah ideals It is hoped that this paper sheds some light on why the Meiri (Babylonian Talmud, Berachot 19b) proclaims that the attribute of kvod habriot is very precious and there is no virtue more beloved than it.

What this paper has attempted to demonstrate is how fundamental human dignity is to Jewish law. What is especially interesting is how a theistic religion in which love and fear of God is paramount, does not minimize the importance of human dignity. In many cases, human dignity trumps even divine law.

As we all know, it is very easy to ignore human dignity in the name of a supposedly higher cause. The failure of many political, religious, and economic systems may be partially due to the total disregard of the importance of human dignity. For example, many communist regimes claimed that they were concerned about the rights of labor; they even renamed their countries "People's Republic." With time it became clear that human dignity was not valued by these regimes. Democratic countries have also made mistakes when it came to human dignity. In the United States, the rights of Japanese-Americans were disregarded during World War II by placing them in detention camps. More recently, human dignity has been disregarded in several American military detention centers. Weintraub (2005) uses the concept of human dignity in Jewish sources to demonstrate that the degradation of human beings in military custody 
cannot be justified even if we are at war.

Shermer (2008) feels that Enron became corrupt because CEO Jeff Skilling created a corporate culture where human dignity was irrelevant. Skilling was a social Darwinist and wanted to set up a firm where there was "survival of the fittest." All employees were ranked on a scale of 1 to $5 ; 20 \%$ of those ranked 5 had to be fired. These rankings were on a website along with pictures of the employee. Humiliation was to be used as a way of motivating employees. As Shermer notes: "Once you set up an environment like that, people begin violating rules."

Radical Islam will ultimately fail because of the low value placed on human dignity. Capitalism and democracy, on the other hand, will thrive only as long as they continue to respect the importance of human dignity.

\section{References}

Amsel, Nachum (1994). The Jewish Encyclopedia of Moral and Ethical Issues. Northvale, New Jersey: Jason Aronson, Inc.

Aramesh, Kiarash (2007). "Human Dignity in Islamic Bioethics." Iran Journal Allergy Asthma Immunology, February, 6 (Suppl. 5), 25-28. Retrieved June 24, 2008 from http://www.iaari.hbi.ir/journal/archive/articles/v6s5ara.pdf

Besdin, Abraham R. (1979). Reflections of the Rav. Jerusalem: World Zionist Organization.

Dratch, Mark (2006, December 6). "The Divine Honor Roll: Kevod ha-Beriyot (Human Dignity) in Jewish Law and Thought." The Jewish Institute Supporting an Abuse-Free Environment. Retrieved June 25, 2008 from http://www.jsafe.org/pdfs/Kevod_Habriyot.pdf

Feldman, Daniel Z. (2005). The Right and the Good. New York: Yashar Books.

Friedman, Hershey H. (2003). “The Simple Life: The Case Against Ostentation in Jewish Law.” Jewish Law. Retrieved June 25, 2008 from http://jlaw.com/Articles/againstosten.html

Hertz, Joseph H. (1959). Authorized Daily Prayer Book. New York: Bloch Publishing Company. 
Jachter, Howard (2001). "Taking Medicine on Shabbat - Part II.” Retrieved July 4, 2008 from http://www.koltorah.org/ravj/medicONshabbat2.htm

Meir, Yair (1990). "The Electric Wheelchair on Shabbat." In Ezra Rosenfeld, ed., Crossroads: Halacha and the Modern World, Vol. III, pp. 97 - 107, Alon Shvut-Gush Etzion, Israel: Zomet Institute.

Rakover, Nahum (1998). Human Dignity in Jewish Law. In Hebrew. Jerusalem: The Jewish Legal Heritage Society.

Shermer, Michael (2008). "Evolution, Compassion, and the Corporation.” In Character, Spring, 4(1), 22 -27 .

Weintraub, Melissa (2005). "Kvod Ha-Briot: Human Dignity in Jewish Sources, Human Degradation in American Military Custody.” Rabbis for Human Rights. Retrieved June 25, 2008 from http://www.rhr-na.org/kvod_habriot/treatise

Weiss, Abner (1991). Death and Bereavement: A Halachic Guide. Hoboken, NJ: Ktav Publishing. 